\title{
Growth, yield and leaf nutrient content of organically grown banana plants in the Canary islands
}

Carlos Enrique Alvarez ${ }^{*}$ Andrés Ortega, Marino Fernández, Andrés Antonio Borges

Instituto de Productos Naturales y Agrobiología, CSIC, Avenida Astrofísico Francisco Sánchez, 3, La Laguna, 38206 Tenerife, Spain
${ }^{*}$ Correspondence and reprints

Received 14 April 2000 Accepted 10 October 2000

Fruits, 2001, vol. 56, p. 17-26 (C) 2001 Cirad/EDP Sciences All rights reserved

Resumen Español, p. 26

\section{Growth, yield and leaf nutrient content of organically grown banana plants in the Canary islands.}

Abstract - Introduction. To compare the mineral nutrition of organically and normally grown banana plants, observations were made on growth and yield of organic banana plants, at the Canary Islands. The data were then discussed opposite the results previously reported for conventional plantations. Materials and methods. Growth parameters (plant height, leaf emission rate, pseudostem circumference) and yield parameters (bunch weight, number of hands, finger grade, etc.) were measured during ten months on an organically grown banana plantation of Dwarf Cavendish cv. Leaf N, P, K, Ca, Mg, Cu, Fe, Mn and Zn contents were also assessed. Results and discussion. Leaf emission rates showed higher values in late spring and early summer $\left(0.099-0.109\right.$ leaf. $\left.\mathrm{d}^{-1}\right)$, while pseudostem circumference grew more in late spring $\left(0.238 \mathrm{~cm} \cdot \mathrm{d}^{-1}\right)$ than in summer. In August, pseudostem circumference decreased dramatically, probably because the plants with a larger circumference had flowered before that month and could not be measured. Bunches gave good yields for the zone (43.59 kg on average) and had a high mean number of hands (12.79). Number of fingers of the second upper hand $(25.63)$, their grade $(37.63 \mathrm{~cm})$, length $(23.50 \mathrm{~cm})$ and weight $(165.19 \mathrm{~g})$ ranged from normal to high. Month of harvesting influenced yield and quality of the fruits. Leaf content of $\mathrm{N}, \mathrm{P}, \mathrm{Mg}, \mathrm{Cu}, \mathrm{Fe}, \mathrm{Mn}$ and $\mathrm{Zn}$ fell within the normal range related to the conventionally grown banana plants. Potassium foliar content showed low levels but not deficiencies, whereas $\mathrm{Ca}$ leaf concentrations were high but not excessive. No relationship was found among leaf nutrient levels and growth, yield and fruit quality parameters.

Canary Islands / Musa / organic agriculture / plant nutrition / growth / yields / mineral content

\section{Croissance, rendement et teneur minérale des feuilles de bananiers de culture biologique, aux Canaries.}

Résumé - Introduction. Pour comparer la nutrition minérale de bananiers issus de cultures biologique ou industrielle, des observations sur la croissance et le rendement de plants menés en culture biologique ont été faites pendant dix mois aux îles Canaries. Les données ont été ensuite discutées vis-à-vis de résultats précédemment publiés pour les plantations conventionnelles. Matériel et méthodes. Sur une plantation de bananiers Cavendish menée en culture biologique au sud de Ténérife, des paramètres de croissance (hauteur de la plante, rythme d'émission foliaire, circonférence de la pseudotige) et des paramètres de rendement (poids du régime, nombre de mains, calibre des doigts, etc.) ont été mesurés pendant dix mois. La teneur foliaire en $\mathrm{N}, \mathrm{P}, \mathrm{K}, \mathrm{Ca}, \mathrm{Mg}, \mathrm{Cu}, \mathrm{Fe}, \mathrm{Mn}$ et $\mathrm{Zn}$ a été également évaluée. Résultats et discussion. L'émission foliaire a été plus élevée en fin de printemps et en début d'été $\left(0,099-0,109\right.$ feuille.jour $\left.^{-1}\right)$, alors que la circonférence de la pseudotige augmentait davantage en fin de printemps $\left(0,238 \mathrm{~cm}^{\circ} \mathrm{jour}^{-1}\right)$ qu'en été. En août, la circonférence de la pseudotige a beaucoup diminué, sans doute parce que les plants les plus larges avaient déjà fleuri et ne pouvaient donc pas être mesurés. Les régimes ont eu un bon rendement moyen $(43,59 \mathrm{~kg})$ pour la zone et un nombre de mains élevé $(12,79$ en moyenne). Le nombre de doigts $(25,63)$ de la deuxième main, leur calibre $(37,63 \mathrm{~cm})$, leur longueur $(23,50 \mathrm{~cm})$ et leur poids $(165,19 \mathrm{~g})$ se sont situés dans des limites normales ou les ont dépassées. Le mois de récolte a influencé le rendement et la qualité des fruits. La teneur foliaire en $\mathrm{N}, \mathrm{P}, \mathrm{Mg}, \mathrm{Cu}, \mathrm{Fe}, \mathrm{Mn}$ et $\mathrm{Zn}$ a été comparable à celle des bananiers cultivés en plantations conventionnelles. La teneur foliaire en $\mathrm{K}$ a été faible sans provoquer de déficiences, tandis que les concentrations en Ca ont été élevées sans être excessives. Aucune relation n'est apparue entre les niveaux de nutrition foliaire et les paramètres de croissance, rendement et qualité du fruit.

Canaries (îles) / Musa / agriculture biologique / nutrition des plantes / croissance / rendement / teneur en éléments minéraux 


\section{Introduction}

In a study to evaluate the sustainability of alternative farming systems, Ikerd et al. concluded that the organic farming system is likely to be more environmentally sound because it would require fewer commercial inputs and result in less loss of topsoil [1]. This alternative system also appears economically preferable because of its higher direct farm income, and it may be more socially responsible, as indicated by its greater potential for local employment opportunities. Nevertheless, Duram [2] pointed out some obstacles to the adoption of organic methods. The first was the lack of stabilization of organic markets and the problem to provide consumer confidence in organic products. The second involved confronting conventional traditions, that perhaps could be remedied by making organic methods more acceptable and accessible through mainstream agricultural outreach. The third was a lack of information. These obstacles could be overcome through policy, research and education.

Organic banana farming faces these obstacles, and most of the information comes from research into conventional banana plantations. However, some work has been reported on organically grown banana plants.

Alvarez et al. [3] studied the fertility of soil and mineral nutrition of an organic banana plantation. They concluded that soil organic matter, phosphorus $(\mathrm{P})$, calcium $(\mathrm{Ca})$ and potassium $(\mathrm{K})$ contents were higher than the average for conventional plantations, and foliar nutrient contents fell within the range considered as normal. Piqué et al. [4] reached out similar conclusions when they studied micronutrient contents in soil and banana leaves from organic banana plantations, but they detected a negative correlation between soil organic matter content and foliar manganese (Mn) levels, probably due to the formation of manganese-organic complexes of low solubility [5].

Information about development and yield indexes mainly comes from data of conventional banana plants. In the Canary
Islands, Rodríguez [6] took data of the number of leaves issued in a banana plantation from April 1997 until the end of September 1997, in plants of the cultivar Dwarf Cavendish. He observed that the number of issued leaves fluctuated between 15.2 and 18.2, and that the rate of emission was not constant. This author measured the circumference of the pseudostem at a height of $1 \mathrm{~m}$ from the soil, and he found an increase of $23.5 \mathrm{~cm}$ to $33 \mathrm{~cm}$ over that period, and irregularities in growth. On the other hand, Soto [7] noted that many authors have reported a positive correlation between the circumference of the pseudostem and the bunch weight. In the Canary Islands, Fernández and García [8] and Díaz [9] also reported a high positive correlation between both parameters.

As far as the fruit of the cultivar Valery is concerned, when a bunch has reached its maximum growth some time before harvesting, it can weigh from $19.2 \mathrm{~kg}$ for bunches of six hands up to $45.50 \mathrm{~kg}$ for bunches of eleven hands. The cultivar Grande Naine produces $17.48 \mathrm{~kg}$ for bunches of six hands up to $45.41 \mathrm{~kg}$ with eleven hands. During bunch growth, the first hands weigh more than the last ones. Percentage variation of weight between the first hand and the number- 9 hand of a bunch of nine hands is about $41.5 \%$ in cultivar Valery, and about $43.8 \%$ in cultivar Grande Naine. As far as the peduncle growth is concerned, its weight shows little variation in relation to fruit size [7]. The same author has reported that finger length bears a linear relationship to fruit size (number of hands), with its position in the bunch (hand position in the peduncle), and with the number of fingers per hand. Bunches with six hands have smaller fingers than bunches with nine hands. The fingers of the upper hands are longer than those of lower hands, so that fingers decrease $0.62 \mathrm{~cm}$ from one hand to the lower one in cultivar Valery, and $0.52 \mathrm{~cm}$ in cultivar Grande Naine.

Finger diameter is known also as finger grade. It is greater in the two upper hands and decreases gradually 0.5 grades, per hand, in the lower hands. The difference of grade between the first and the last hand 
varies in relation to the bunch size from 2.0 grades for bunches of six hands up to 4.9 grades for bunches of ten hands. These differences prove very important at cropping, because most markets only accept fruits of 34.9 grades or higher [7, 10].

Fernández et al. [11] took samplings of fruits of the cultivar Dwarf Cavendish at harvest time. They measured several physical parameters of growth such as bunch weight, number of hands, number of fingers of the upper second hand, finger length measured by its convex part, and finger fullness index (weight/length). These authors observed that $88 \%$ of bunches had weights greater than $22 \mathrm{~kg}$, and that bunches of greater weight coincided with a higher number of hands and a higher number of fingers per hand (second upper hand). Finger length ranged between 17.5 and $20 \mathrm{~cm}$, while finger weight fluctuated between 90 and $130 \mathrm{~g}$.

Mineral nutrition plays an important role in relation to the parameters already discussed. Nitrogen $(\mathrm{N})$ generates banana growth and vegetable matter production [7], but, if the critical $\mathrm{N}$ level is surpassed, any increase in this element have tends to lead to a decrease in pseudostem circumference [8]. Phosphorus prevents premature ageing of the leaves and aids growth of young independent plants, although it influences bunch weight only in event of an intense and prolonged deficiency [12]. On the other hand, $\mathrm{K}$ has a determinant action on bunch weight and number of hands, and on pseudostem size [13]. While Ca has scarcely any effect on the quantitative yield, it improves fruit quality and decreases peel bursting [12]. This author has reported that Mg affects growth regulation positively, and promotes yields quantitatively and qualitatively. As far as micronutrients are concerned, copper $(\mathrm{Cu})$ and iron $(\mathrm{Fe})$ contribute to leaf growth [12, 14], whereas Mn and $\mathrm{Zn}$ improve bunch formation and filling [12].

To compare the mineral nutrition of organically and conventionally grown banana plants, observations were made on growth and yield of organic banana plants at the Canary Islands during ten months.
The data were then discussed opposite the results previously reported for industrial plantations.

\section{Materials and methods}

\subsection{Experiment characteristics}

An experiment was carried out in a $4200 \mathrm{~m}^{2}$ plantation of organically grown banana plants, located on the South coast of Tenerife (Spain). The banana cultivar was Gruesa Palmera, an improved clone of the cultivar Dwarf Cavendish. Banana plants were vegetatively propagated by bulb pieces in a tree nursery, and then transplanted to the farm on July 1997. Tissue-culture planting material was not used because the tree nursery had only rhizomes for propagation.

The experiment was concluded in February 1999. Soil was analyzed before and after the trial.

\subsection{Fertilisation}

Fertilisation consisted of cow urine, Phenix, Patenkali and horse manure. Cow urine was mixed daily with irrigation water, varying its proportion by season and plant growth. Throughout the growth cycle, cow urine total application was $3841 \mathrm{cL}$ per plant. It contained $2.58 \mathrm{~g} \cdot \mathrm{L}^{-1} \mathrm{~N}, 0.46 \mathrm{~g} \cdot \mathrm{L}^{-1} \mathrm{P}$, $14.99 \mathrm{cmol} \cdot \mathrm{L}^{-1} \mathrm{~K}, 0.10 \mathrm{cmol} \cdot \mathrm{L}^{-1} \mathrm{Ca}$ and $1.79 \mathrm{cmol} \cdot \mathrm{L}^{-1} \mathrm{Mg}$. Phenix, an organic fertiliser consisting of a mixture of beetroot extract and chicken manure, contained $60 \mathrm{~g} \cdot \mathrm{kg}^{-1} \mathrm{~N}, 80 \mathrm{~g} \cdot \mathrm{kg}^{-1} \mathrm{P}, 150 \mathrm{~g} \cdot \mathrm{kg}^{-1} \mathrm{~K}$, $40 \mathrm{~g} \cdot \mathrm{kg}^{-1} \mathrm{Ca}, 20 \mathrm{~g} \cdot \mathrm{kg}^{-1} \mathrm{Mg}, 10 \mathrm{~g} \cdot \mathrm{kg}^{-1}$ micronutrients and $560 \mathrm{~g} \cdot \mathrm{kg}^{-1}$ organic matter. It was dressed at a rate of $700 \mathrm{~g}$ per plant. Patenkali (300 g. $\mathrm{kg}^{-1} \mathrm{~K}_{2} \mathrm{O}$ and $100 \mathrm{~g} \cdot \mathrm{kg}^{-1} \mathrm{MgO}$ ) was dressed at a rate of $400 \mathrm{~g}$ per plant. Finally, $45 \mathrm{~kg}$ per plant of horse manure were added. Its composition was $74.5 \mathrm{~g} \cdot \mathrm{kg}^{-1}$ organic matter, $15.1 \mathrm{~g} \cdot \mathrm{kg}^{-1} \mathrm{~N}$, $2.9 \mathrm{~g} \cdot \mathrm{kg}^{-1} \mathrm{P}, 48.6 \mathrm{~g} \cdot \mathrm{kg}^{-1} \mathrm{~K}, 20.0 \mathrm{~g} \cdot \mathrm{kg}^{-1} \mathrm{Ca}$, $5.2 \mathrm{~g} \cdot \mathrm{kg}^{-1} \mathrm{Mg}$, and $6 \mathrm{~g} \cdot \mathrm{kg}^{-1}$ micronutrients. No fresh chicken or horse manure was added as fertilizer, though they are in line with organic products regulations. Total 
main nutrients dressed per plant were $821.1 \mathrm{~g} \mathrm{~N}, 205 \mathrm{~g} \mathrm{P}$, and $2331 \mathrm{~g} \mathrm{~K}$.

\subsection{Cultural practices}

\subsubsection{Spacing}

Rhizomes were planted in paired lines, placing the lines of plants on both sides of the irrigation pipe. Distance between lines was $1 \mathrm{~m}$, while the distance between plants in the same line was $2 \mathrm{~m}$. Separation between paired lines to form passages was $5 \mathrm{~m}$.

\subsubsection{Irrigation}

A drip-irrigation system was used. Irrigation was scheduled in accordance with data from a nearby meteorological station. Irrigation doses ranged from $16 \mathrm{~L}$ per plant and day in winter, up to $25 \mathrm{~L}$ per plant and day in summer.

\subsubsection{Weed control}

No chemical weed control is allowed in organic agriculture. Weeds were cut or pulled out by hand or by using a hoe.

\subsubsection{Pest and disease incidence and control}

The most important pests that affected banana plants were Dysmicoccusalazon W., Aspidiotus elaiedis M., A. heredae V. and Crysompholus ficus A. Products such as potash soap (10 L per $1000 \mathrm{~L}$ of water) with $1.8 \mathrm{~kg}$ of tobacco powder were used for pest control, in addition to rotenone extracted from Derris sp., Lonchocarpus sp. and Tephrosa sp.

Nematodes (Pratylenchus sp. and Meloidogyne sp.) were combated with neem (azadiractine) extracted from Azaridacta indica at a dose of $2 \mathrm{~L} \cdot 5000 \mathrm{~m}^{-2}$, applying Biomore (culture of microbes antagonist of nematodes) (5 L.5000 $\mathrm{m}^{-2}$ ) the following day.

The most outstanding disease was Panama disease caused by Fusarium oxysporum f. sp. cubense. To control it, diseased plants were cut down and removed, using disinfected tools, and lime was also used sporadically.

\subsection{Parameters measured}

The parameters measured were the leaf emission rate (LER); the pseudostem circumference at a height of $1 \mathrm{~m}$ from the soil; the pseudostem height at the beginning and at the end of the trial: this height was measured from the soil up to the " $\mathrm{V}$ " formed by the petioles of the two last issued leaves fully unfolded; the bunch weight with and without peduncle; the number of hands of the bunch, and number of fingers of the second upper hand; the length, grade and weight of the representative finger (central external finger) of the second upper hand.

The height was measured at the beginning and at the end of the trial with a $5 \mathrm{~m}$ metal tape. Final height was measured just before bunch cropping.

For mesuring the leaf emission rate (LER), petioles of every leaf were numbered off, matching number 0 with the last issued leaf (still unfolded), and registering the stage of this leaf in accordance with the Brun's scale [15]. Data were taken once every two weeks from March until August 1998.

Pseudostem circumference was measured carried out with a cloth-plastic tape, and over the same period and with the same frequency as the LER.

Bunch total weight was measured at bunch harvesting with a digital weighing machine.

For obtaining weight of the without peduncle bunches, all the peduncles were marked prior to removal, to know from which bunch they came. After hand removing of the bunches, peduncles were weighed and their weights were subtracted from their matching bunch total weights.

Number of hands per bunch and number of fingers of the second upper hand were recorded one or two days before harvesting.

The finger length, grade and weight were measured at bunch harvesting. Every finger was marked. Length was measured by a cloth-plastic tape, grade by a calliper, and finger weight by a digital balance. 


\subsection{Foliar sampling and analysis}

Banana leaves were taken following the recommendations of the Banana Foliar Analysis Standardization Seminar (Tenerife, 1975), as described by Piqué et al. [4]. The samples were washed in distilled water and dried in an oven at $80{ }^{\circ} \mathrm{C}$, after which they were ground to powder. To determine $\mathrm{N}$ by the Kjeldahl method [16], $0.2 \mathrm{~g}$ of this powder was used. A further $1 \mathrm{~g}$ of the powder was ashed in an oven at $480{ }^{\circ} \mathrm{C}$ for $4 \mathrm{~h}$ and then digested in $6 \mathrm{M}$ hydrochloric acid [17]. $\mathrm{K}, \mathrm{Ca}, \mathrm{Mg}, \mathrm{Cu}, \mathrm{Fe}, \mathrm{Mn}$ and $\mathrm{Zn}$ were determined by atomic absorption spectrophotometry, and $\mathrm{P}$ by the vanadate-molybdate method [17].

\subsection{Data analysis}

To measure the parameters of this study, 120 plants were chosen among those that had a similar growth. These 120 plants were assigned to four plots of 30 plants each.

Data base was Microsoft Excel for Windows 95, version 7.0, and statistics (Student's t test, coefficient of variation, Anova and correlations) were carried out by Statgraphics plus 2.1 for Windows.

\section{Results and discussion}

\subsection{Soil analysis}

An increase of soil pH was observed after the trial, probably because the $\mathrm{pH}$ of the added horse manure was slightly alkaline (table I). The fertilization could be also responsible of the increases of available $\mathrm{K}$, $\mathrm{Ca}$ and $\mathrm{Mg}$, meanwhile the decrease of $\mathrm{Na}$ and electric conductivity might be due to leaching caused by irrigation. Nutrient content of the soil was normal according to the data reported by Alvarez et al. [3] and Diaz [9].

\subsection{Plant height}

Plants of similar growth were chosen mainly on the basis of initial height (table II) in order to distribute the banana plants to be sampled. According to Soto [7], final mean height $(2.09 \mathrm{~m})$ shows that Gruesa Palmera is a clone of Dwarf Cavendish. It is not surprising that apparent new clones of the main banana strain of Dwarf Cavendish appear in the Canary Islands, because Stover and Simmonds [10] pointed out that any large-scale cultivation that started with one clone would, in the course of years, come to possess every member of the group. This fact let us compare our data with those from other authors who have studied the Dwarf Cavendish under conventional cultivation in the same area.

\subsection{Leaf emission rate}

Leaf emission showed a higher rhythm within the period between May 15 and July 16,1998 , and their means ranged from 0.099 up to 0.109 leaves. $^{-1}$ (table III). On the other hand, the lowest leaf emission rhythm took place between April 15 and May 15, 1998, with a mean of 0.078 leaf. $\mathrm{d}^{-1}$. With Dwarf Cavendish cultivated in conventional

Table I.

Soil analysis before and after the trial carried out in the Canary Islands to study the growth of organically grown banana plants.

$\begin{array}{lccccccccc}\text { Analysis time } & \mathrm{pH} & \begin{array}{c}\text { Organic } \\ \text { matter } \\ \left(\mathrm{g} \cdot \mathrm{kg}^{-1)}\right.\end{array} & \begin{array}{c}\mathrm{P} \\ \left(\mathrm{mg} \cdot \mathrm{kg}^{-1)}\right.\end{array} & & \begin{array}{c}\text { Available cations } \\ \left(\mathrm{cmol}^{-1} \mathrm{~kg}^{-1}\right)\end{array} & & \begin{array}{c}\text { Electric } \\ \text { conductivity } \\ \left(\mathrm{dS} \cdot \mathrm{m}^{-1}\right)\end{array} \\ \text { Before trial } & 6.83 & 36.3 & 160 & 15.6 & 146.1 & 33.4 & 39.9 & 4.35 \\ \text { After trial } & 7.32 & 45.8 & 143 & 48.1 & 199.8 & 73.6 & 32.4 & 3.35\end{array}$




\section{Table II.}

Measurement of initial and final heights of pseudostem and bunch, and of yield parameters for plants of a trial studying organically grown banana plants in the Canary Islands.

\begin{tabular}{|c|c|c|c|c|c|c|c|c|c|c|}
\hline \multirow[t]{3}{*}{ Parameter } & \multirow{2}{*}{\multicolumn{2}{|c|}{$\begin{array}{l}\text { Pseudostem height } \\
\qquad(\mathrm{cm})\end{array}$}} & \multirow{2}{*}{\multicolumn{2}{|c|}{$\begin{array}{l}\text { Bunch weight } \\
(\mathrm{kg})\end{array}$}} & \multirow{3}{*}{$\begin{array}{l}\text { Number } \\
\text { of hands }\end{array}$} & \multicolumn{2}{|c|}{ Fingers of second upper hand } & \multicolumn{3}{|c|}{ Finger } \\
\hline & & & & & & \multirow[t]{2}{*}{ Number } & \multirow[t]{2}{*}{ Plenitude index ${ }^{1}$} & \multirow{2}{*}{$\begin{array}{l}\text { grade } \\
(\mathrm{mm})\end{array}$} & \multirow{2}{*}{$\begin{array}{l}\text { length } \\
(\mathrm{cm})\end{array}$} & \multirow{2}{*}{$\begin{array}{l}\text { weight } \\
\text { (g) }\end{array}$} \\
\hline & Initial & Final & With peduncle & Without peduncle & & & & & & \\
\hline Mean & 135.79 & 208.95 & 43.59 & 40.16 & 12.79 & 25.63 & 6.84 & 37.63 & 23.50 & 165.19 \\
\hline $\begin{array}{l}\text { Coefficient } \\
\text { of variation }\end{array}$ & 2.45 & 2.06 & 1.65 & 2.26 & 1.09 & 2.78 & 3.80 & 1.35 & 1.15 & 2.13 \\
\hline
\end{tabular}

plantations in the same area as our trial, Rodríguez [6] found that between April 19 and September 27, 1997, the number of issued leaves ranged from 13.8 up to 18.2. He observed that the period with a greater leaf emission rate began on May 18 and finished on May 31 of the same year, with a mean of 0.124 leaf $\cdot d^{-1}$. The lower rate was recorded throughout the period between April 19 and May 18, with a mean of 0.0796 leaf.d $\mathrm{d}^{-1}$. These results contrast with those obtained by Galán [18] in conventional plantations of the south-east and south-west of Tenerife, where the greater leaf emission rate took place in August, with a mean of four leaves issued in plantations in the south-east $\left(0.13\right.$ leaf. $\left.\mathrm{d}^{-1}\right)$, and a mean of 3.4 leaves in farms in the southwest $\left(0.11\right.$ leaf. $\left.d^{-1}\right)$. Thus, our results are closer to those reported by Rodríguez [6] than those found by Galán [18]. The explanation may be that Rodríguez [6] data were taken under environmental conditions more similar to those of our trial, as far as location and banana growth are concerned.

\subsection{Pseudostem circumference}

The greater growth of the pseudostem circumference took place between May 16 and June 13, 1998, with a growth of $0.238 \mathrm{~cm} \cdot \mathrm{d}^{-1}$ (table IV).Then, at the next samplings, growth was lower and even negative, probably due to the fact that banana plants with a smaller pseudostem circumference have a late growth. Rodríguez [6] detected increases in the pseudostem circumference from 23.5 up to $33 \mathrm{~cm}$, between April 19 and September 27, 1997, in the same area as our trial. He observed the greatest growth in the measurements made between May 18

\section{Table III.}

Banana plant leaf emission from March 15 through August 13, 1998, in a trial studying organically grown banana plants at the Canary Islands.

\begin{tabular}{lcrrrr} 
Statistical parameters & \multicolumn{5}{c}{ Date of measurement } \\
& 15 April & 15 May & 13 June & 16 July & 13 August \\
Leaf emission cumulated mean & 2.32 & 4.67 & 7.55 & 11.15 & 13.64 \\
Coefficient of variation & 1.42 & 2.01 & 1.31 & 3.28 & 2.01 \\
Student's $t$ value $(p$ value $=0)$ & - & -47.027 & -42.203 & -18.935 & -10.876 \\
Mean leaf emission per day & - & 0.078 & 0.099 & 0.109 & 0.089
\end{tabular}




\section{Table IV.}

Pseudostem circumference from April 18 through August 13, 1998, and at bloom stage for organically grown banana plants cultivated at the Canary Islands.

\begin{tabular}{|c|c|c|c|c|c|c|}
\hline \multirow[t]{2}{*}{ Statistical parameters } & \multicolumn{5}{|c|}{ Date of measurement } & \multirow[t]{2}{*}{ Bloom stage } \\
\hline & 18 April & 16 May & 13 June & 16 July & 13 August & \\
\hline Pseudostem circumference mean (cm) & 56.67 & 59.86 & 66.53 & 70.80 & 68.22 & 72.38 \\
\hline Coefficient of variation & 4.60 & 4.68 & 3.38 & 2.37 & 2.33 & 0.90 \\
\hline Student's $t$ value & - & -1.674 & -3.716 & -3.037 & -2.279 & -5.036 \\
\hline$p$ value & - & 0.145 & 0.010 & 0.023 & 0.063 & 0.002 \\
\hline Pseudostem circumference increase per day ${ }^{1}$ & - & 0.114 & 0.238 & 0.129 & -0.092 & - \\
\hline
\end{tabular}

and 31, 1997, with a mean of $0.261 \mathrm{~cm} \cdot \mathrm{d}^{-1}$, while the smaller increases took place between September 11 and 27 of the same year, with a mean of $0.089 \mathrm{~cm} \cdot \mathrm{d}^{-1}$.

A positive correlation was detected between the pseudostem circumference at blossom and the number of fingers of the second upper hand $(r=0.71, p=0.01)$. However, the relations between the pseudostem circumference and the bunch weight reported by Soto [7], Díaz [9], and Fernández and García [19] were not observed.

\subsection{With and without peduncle bunch weight}

Mean bunch total weight was $43.59 \mathrm{~kg}$, decreasing $3.43 \mathrm{~kg}$ when raquis mean weight was substracted (table II).

Significant differences were detected depending on the month of harvest, thus, cropping time influenced bunch weights (table V). Total weight mean of bunches harvested in December was $45.11 \mathrm{~kg}$ and significantly differed from that of bunches harvested in February, which was $36.10 \mathrm{~kg}$. As far as bunch weight without peduncle is concerned, data of November $(40.61 \mathrm{~kg})$ and December $(41.50 \mathrm{~kg})$ showed significant differences from those of February $(32.90 \mathrm{~kg})$. Robinson and Nel [20] have reported that bunch weight varied depending upon blossom time. The yields obtained in our trial can be considered to be normal if other works carried out in conventional plantations of the same cultivar in the Canary Islands are taken into account. Acosta [21] measured a mean bunch weight of $38.7 \mathrm{~kg}$. Fernández et al. [11] observed a $12-46 \mathrm{~kg}$ range of weights; these values were very similar to those (20-46 kg) found by Díaz [9]. Rodríguez [6] reported a mean bunch weight without peduncle of $40.91 \mathrm{~kg}$.

\subsection{Number of hands per bunch}

Mean number of hands per bunch was 12.79 (table II), however, harvest time influenced this number (table V). Thus, the number of hands per bunch ranged from 12.07 to 13.00, and significant differences were recorded among fruits harvested in October and those harvested during the other months. The number of hands per bunch reported by Díaz ranged between 11.6 and 15.5 [9], while Fernández et al. observed variations from 6 up to 17 [11]. Means found by Rodríguez [6] for the south (12.64 hands) and north (12.57 hands) areas of Tenerife (Canary Islands) fitted these intervals. Acosta reported a mean value of 11.21 hands [21] and noted that bunches which weighed more than $30 \mathrm{~kg}$ had 14 or more hands. However, this observation did not happen in our trial, since both the lowest mean bunch weight ( $36.10 \mathrm{~kg}$ ) and the greatest one $(45.11 \mathrm{~kg})$ coincided with a mean of 13 hands per bunch (table V). 
Table V.

Yield parameters of organically grown banana plants according to the month of harvest at the Canary Islands.

\begin{tabular}{|c|c|c|c|c|c|c|c|c|}
\hline \multirow{2}{*}{$\begin{array}{l}\text { Month } \\
\text { of harvest }\end{array}$} & \multicolumn{2}{|c|}{ Bunch weight (kg) } & \multirow{2}{*}{$\begin{array}{l}\text { Number } \\
\text { of hands }\end{array}$} & \multicolumn{2}{|c|}{ Finger of second superior hand } & \multicolumn{3}{|c|}{ Finger } \\
\hline & With peduncle & without peduncle & & Number & Plenitude index ${ }^{1}$ & Grade $(\mathrm{mm})$ & Length (cm) & Weight (g) \\
\hline October & $41.35 \mathrm{bc}$ & $39.21 \mathrm{ab}$ & $12.07 \mathrm{~b}$ & 26.71 & $6.83 a b$ & $38.27 \mathrm{a}$ & $23.05 b$ & $169.48 a b$ \\
\hline November & $44.25 a b$ & $40.61 \mathrm{a}$ & $12.85 \mathrm{a}$ & 26.26 & $7.10 \mathrm{a}$ & $37.54 \mathrm{a}$ & $23.31 \mathrm{~b}$ & $165.53 \mathrm{a}$ \\
\hline December & $45.11 \mathrm{a}$ & $41.50 \mathrm{a}$ & $13.00 \mathrm{a}$ & 25.09 & $6.91 \mathrm{ab}$ & $37.78 \mathrm{a}$ & $23.52 \mathrm{ab}$ & $162.70 \mathrm{a}$ \\
\hline January & $43.16 \mathrm{ab}$ & $38.75 \mathrm{ab}$ & $12.80 \mathrm{a}$ & 24.53 & $6.98 a b$ & $37.57 \mathrm{a}$ & $24.08 \mathrm{a}$ & $168.45 \mathrm{a}$ \\
\hline February & $36.10 \mathrm{c}$ & $32.90 \mathrm{~b}$ & $13.00 \mathrm{a}$ & 28.25 & $5.88 \mathrm{~b}$ & $33.87 \mathrm{~b}$ & $23.00 \mathrm{~b}$ & $135.53 b$ \\
\hline Significance $^{2}$ & ** & ** & ** & ns & ** & ** & ** & ** \\
\hline
\end{tabular}

\subsection{Number of fingers of the second upper hand}

The second upper hand presented a mean of 25.63 fingers (table II), and no significant differences were observed among the months of cropping (table V). Rodríguez reported out a mean of 25.71 fingers in the south area of Tenerife, and a mean of 25.57 fingers in the north area [6]. These data are greater than those recorded by Acosta who observed a mean of 22.51 fingers [21], and those of Fernández et al., who obtained means from 10 to 23 fingers [11].

\subsection{Characteristics of the representative finger of the second upper hand}

\subsubsection{Finger grade}

The mean diameter of all the fingers measured was $37.63 \mathrm{~mm}$ (table II). However, significant differences were detected between fingers harvested in February which had the lower grade and those of the other months (table V). The finger grade mean of 36.21 $\mathrm{mm}$ reported by Acosta [21] was slightly lower than the means obtained in our trial.

As expected, the grade of the fingers and their weights were closely related by a positive significant correlation $(r=0.70$, $\mathrm{p}=0.01$ ).

\subsubsection{Finger length}

The mean finger length of $23.50 \mathrm{~cm}$ (table II) was influenced by the month of harvest: fingers harvested in January were significantly longer than those from bunches harvested in October, November and February (table V). Acosta obtained a mean finger length of $24.35 \mathrm{~cm}$ [21], while Fernández et al. found lengths that ranged from 12.5 up to $21 \mathrm{~cm}$ [11]. Our data fell halfway between those reported by these authors.

\subsubsection{Finger weight}

The mean finger weight was $165.19 \mathrm{~g}$ (table II), and, once more, an influence of the harvest time was observed: banana fingers of bunches harvested in February weighed significantly less than those of the other months, except for October (table V). Acosta observed a mean finger weight of $196.31 \mathrm{~g}$ [21], and Fernández et al. measured weights that ranged between 56.7 and $140.3 \mathrm{~g}$ [11].

\subsection{Finger fullness index}

The finger fullness index of a representative finger of the second upper hand, measured as the [finger weight / finger length] ratio, was 6.84 on average, however, fruits harvested in November presented a 
Table VI.

Leaf nutrient content on the dry matter basis for organically grown banana plants at the Canary Islands.

\begin{tabular}{|c|c|c|c|c|c|c|c|c|c|}
\hline \multirow[t]{2}{*}{ Statistical parameter } & Nitrogen & Phosphorus & Potassium & Calcium & Magnesium & Copper & Iron & Manganese & Zinc \\
\hline & \multicolumn{5}{|c|}{$\left(g \cdot \mathrm{kg}^{-1}\right)$} & \multicolumn{4}{|c|}{$\left(\mathrm{mg} \cdot \mathrm{kg}^{-1}\right)$} \\
\hline Mean & 33.78 & 2.30 & 30.08 & 14.78 & 4.73 & 11.8 & 183.5 & 229.3 & 24.3 \\
\hline Coefficient of variation & 4.85 & 3.48 & 5.18 & 7.98 & 2.75 & 4.25 & 1.00 & 1.14 & 13.6 \\
\hline
\end{tabular}

significantly greater fullness index than those harvested on February (table V). Our data are included in the range (4.5-8.2) observed by Fernández et al. in conventional plantations [11].

\subsection{Nutrition contents}

Foliar levels of N, P, Mg, $\mathrm{Cu}, \mathrm{Fe}, \mathrm{Mn}$ and $\mathrm{Zn}$ (table VI) were within the optimum ranges reported by Martin-Prével for conventional plantations [22]. On the other hand, foliar concentration of $\mathrm{K}$ was low, while that of $\mathrm{Ca}$ was high. However, the plants did not show any symptoms of $\mathrm{K}$ deficiency, such as discoloured and faded leaves, stunted bunches and bad fruit fill up [12]. No Ca excess was apparent, which normally leads to a Mg or $\mathrm{K}$ deficiency in plants [14]. Considering other results got in other organically grown banana plant plantations of Tenerife $[3,4], \mathrm{N}, \mathrm{Ca}, \mathrm{Cu}$, $\mathrm{Fe}$ and $\mathrm{Mn}$ contents showed greater values, while those of $\mathrm{K}$ and $\mathrm{Zn}$ were lower. $\mathrm{P}$ and $\mathrm{Mg}$ levels were similar to those reported by Alvarez et al. [3].

In conventional plantations, some works have reported correlations between nutrient leaf levels and growth or yield parameters. Fernández and García [8], García et al. [23] and Díaz [9] observed close relationships between among $\mathrm{N}, \mathrm{Ca}$ and $\mathrm{Mg}$, and pseudostem circumference. Murray [13] and García et al. [23] detected correlations between $\mathrm{K}$ leaf concentration and bunch weight and number of hands per bunch. However, in our results, no relationship was detected between the leaf concentrations of the analysed elements and the studied parameters of growth and yield. This fact may be due to the low dispersion of the data of our experiment.

\section{Acknowledgement}

We acknowledge Mrs. Pauline Agnew who endeavoured to edit the English version of this paper.

\section{References}

[1] Ikerd J., Devino G., Traiyongwanich S., Evaluating the sustainability of alternative farming systems: a case study, Am. J. Alter. Agri. 11 (1997) 25-29.

[2] Duram L.A., Factors in organic farmers' decision-making: diversity, challenge, and obstacles, Am. J. Alter. Agri. 14 (1999) 2-10.

[3] Alvarez C.E., García C., Carracedo A.E., Soil fertility and mineral nutrition of an organic banana plantation in Tenerife, Biol. Agric. Hortic. 5 (1988) 313-323.

[4] Piqué E., Alvarez C.E., Fernández M., Micronutrients in soils and plants from organic farms of Tenerife (Canary Islands), Biol. Agric. Hortic. 13 (1996) 113-122.

[5] Stevenson F.J., Organic matter-micronutrient reactions in soil, in: Mortvedt J.J., Cox F.R., Shumen L.M., Welch R.M. (Eds.), Micronutrients in Agriculture, SSSA Book Series, 4, Madison, 1991, 427-476.

[6] Rodríguez L., Comparación del ritmo de crecimiento y desarrollo al aire libre en las Comarcas noroeste y sur de Tenerife, del cultivar de platanera "Pequeña Enana" (Musa AAA, subgrupo Cavendish): influencia de los factores climáticos. Trabajo fin de carrera, Centro Superior de Ciencias Agrarias, univ. La Laguna, Tenerife, Spain,1998, 158 p.

[7] Soto M., Bananos, cultivo y comercialización, Litografía e Imprenta LIL S.A., San José, Costa Rica, 1990.

[8] Fernández E., García V., Estudio sobre la nutrición del plátano en las islas Canarias, An. Edaf. Agrob. 31 (1972) 917-925. 
[9] Díaz A., Estudio de la fertilidad de los suelos y nutrición mineral de los cultivos de plátanos de Tenerife, Ph D Thesis, univ. La Laguna, Tenerife, Spain, 1975, 238 p.

[10] Stover R.H., Simmonds N.W., Bananas, Longman Scientific and Technical, New York, USA, 1987.

[11] Fernández M., Robles J., Alvarez C.E., Díaz A., Relación entre la composición mineral y el desarrollo de los frutos del plátano, An. Edaf. Agrob. 39 (1980) 2199-2213.

[12] Martin-Prével P., Fisiología de la platanera, Colegio oficial de ingenieros agrónomos, Santa Cruz, Spain, 1979, 78 p.

[13] Murray D.E., The effect of deficiencies of the mayor nutrients on growth and leaf analysis of the banana, Trop. Agr. 37 (1960) 97-106.

[14] Jones B., Wolf H., Mills A., Plant analysis handbook, Micro-Macro Publishing, Inc., Athens, USA, 1991.

[15] Brun J., La cercosporiose du bananier en Guinée. Étude de la phase ascosporée du Mycospharella Leach, Thèse doctorat, Fac. Sci. Univ. Paris Sud/Orsay, 1963.

[16] López J., El diagnóstico de suelos y plantas, Ediciones Mundi-Prensa, Madrid, España, 1990.

[17] Chapman H.D., Pratt P.F., Métodos de análisis para suelos, plantas y aguas, Editorial Trillas, México, 1973.
[18] Galán V., Estudio de la práctica del deshijado y de la fenología de la platanera en la isla de Tenerife, Ph D Thesis, Esc. Univ. Ing. Agrón., Univ. Córdoba, Spain, 1981, 165 p.

[19] Fernández E., García V., Contribution à l'étude de la fertilité des sols de bananeraies de l'île de Ténérife, Fruits 25 (1970) 175-185.

[20] Robinson J.C., Nel J., Comparative morphology, phenology and production potential of banana cultivars "Dwarf Cavendish" and "Williams" in the eastern Transvaal Lowveld, Sci. Hortic. 25 (1985) 146-161.

[21] Acosta A., Aplicación de correctores de carencia de calcio en platanera (Musa acuminata colla $A A A)$. Su influencia en el llenado de la fruta emitida en los meses de invierno, Trabajo fin de carrera, Ctr. Sup. Ciencias Agrarias, Univ. La Laguna, Spain, 1997, 171 p.

[22] Martin-Prével P., Bananier, in: Martin-Prével P., Gagnard P.J., Gautier P. (Éds.), L'analyse vegétale dans le contrôle de l'alimentation des plantes tempérées et tropicales, Lavoisier Techniques et Documentation, Paris, 1984, 715-751.

[23] García V., Fernández E., Díaz A., Alvarez C.E., Efecto de la nutrición potásica en la producción del plátano, Agrochimica 21 (1977) 26-36.

\section{Crecimiento, rendimiento y contenido mineral de hojas de banano de cultivo biológico en las Canarias.}

Resumen - Introducción. Para comparar la nutrición mineral de bananos cultivados convencionalmente y ecológicamente, se llevaron a cabo medidas de crecimiento y producción de plantas de banana ecológicas en las islas Canarias. Los datos se discutieron en contraposición con los resultados previamente referidos para plantaciones convencionales. Material y métodos. Parámetros de desarollo (altura de la planta, proporción de emisión de hojas, circunferencia del pseudotallo) y parámetros de producción (peso del racimo, número de manos, grados de los dedos, etc.) se midieron durante diez meses en una plantación de bananas ecológicas des cv. Dwarf Cavendish) en las islas Canarias. Tambiém se determinaron los contenidos foliares de N, P, K, Ca, Mg, Cu, Fe, Mn y Zn. Resultados y discusión. La proporción de emisión de hojas fue mayor a finales de la primavera y a principios del verano (0.099-0.109 hojas $\left.\cdot \mathrm{d}^{-1}\right)$, mientras que la circunferencia del pseudotallo aumentó más a finales de primavera $\left(0.238 \mathrm{~cm} \cdot \mathrm{d}^{-1}\right)$ que en verano. En Agosto, la circunferencia del pseudotallo disminuyó notablemente, probablemente porque las plantas con mayor circunferencia florecieron antes de ese mes y no pudieron medirse. Los racimos dieron buenos rendimiento para la zona (un media de $43.59 \mathrm{~kg}$ ) y tuvieron un alto número de manos $(12,79)$. El número de dedos de la segunda mano superior $(25,63)$, su grado $(37,63 \mathrm{~cm})$, longitud $(23,50 \mathrm{~cm})$ y peso $(165,19 \mathrm{~g})$ estuvieron entre normales y altos. El mes de cosecha influenció el rendimiento y calidad de los frutos. El contenido foliar de N, P, Mg, $\mathrm{Cu}, \mathrm{Fe}, \mathrm{Mn}$ y Zn se encontró dentro del rango normal referido para bananas convencionales. El contenido foliar de K mostró niveles bajos, pero no deficientes, mientras que el Ca foliar fue alto, pero no excesivo. No se encontró ninguna relación entre los niveles de nutrientes en las hojas y los parámetros de desarollo, rendimiento y calidad de la fruta.

Canarias / Musa / agricultura ecológica / nutrición de las plantas / crecimiento / rendimiento / contenido mineral 